\title{
Review
}

Neuropsychobiology

Neuropsychobiology 2011;64:152-162

DOI: $\underline{10.1159 / 000328950}$
Received: March 27, 2009

Accepted after revision: August 11, 2009

Published online: July 29, 2011

\section{Bright-Light Therapy in the Treatment of Mood Disorders}

\author{
Gerald Pail Wolfgang Huf Edda Pjrek Dietmar Winkler Matthaeus Willeit \\ Nicole Praschak-Rieder Siegfried Kasper \\ Department of Psychiatry and Psychotherapy, Medical University of Vienna, Vienna, Austria
}

\author{
Key Words \\ Depression · Seasonal affective disorder · Chronobiology • \\ Melatonin · Serotonin
}

\begin{abstract}
Bright-light therapy (BLT) is established as the treatment of choice for seasonal affective disorder/winter type (SAD). In the last two decades, the use of BLT has expanded beyond SAD: there is evidence for efficacy in chronic depression, antepartum depression, premenstrual depression, bipolar depression and disturbances of the sleep-wake cycle. Data on the usefulness of BLT in non-seasonal depression are promising; however, further systematic studies are still warranted. In this review, the authors present a comprehensive overview of the literature on BLT in mood disorders. The first part elucidates the neurobiology of circadian and seasonal adaptive mechanisms focusing on the suprachiasmatic nucleus (SCN), the indolamines melatonin and serotonin, and the chronobiology of mood disorders. The SCN is the primary oscillator in humans. Indolamines are known to transduce light signals into cells and organisms since early in evolution, and their role in signalling change of season is still preserved in humans: melatonin is synthesized primarily in the pineal gland and is the central hormone for internal clock circuitries. The melatonin precursor serotonin is known to modulate many behaviours that vary with season. The second part discusses the pathophysiology and clinical specifiers of SAD, which can be seen as a model disorder for chronobiological
\end{abstract}

disturbances and the mechanism of action of BLT. In the third part, the mode of action, application, efficacy, tolerability and safety of BLT in SAD and other mood disorders are explored.

Copyright $\odot 2011$ S. Karger AG, Basel

In the early 1980s, the observation that light is able to shift the circadian phase and seasonal rhythms in animals, and the concept of extending daylight during winter months in order to interfere with these rhythms resulted in the first trial of bright-light therapy (BLT) in seasonal affective disorder (SAD) [1]. Since then, a remarkable number of studies have been able to prove the relevance of BLT in the treatment of seasonal and nonseasonal mood disorders. Moreover, BLT was also investigated in other problems and disorders associated with circadian rhythm disturbances (jet lag, shift work or dementia) [2-5], sleep disorders [6, 7], bulimia nervosa [811] and adult attention-deficit/hyperactivity disorder [12]. The purpose of this article is to give an overview on up-to-date chronobiology research, and to try to elucidate the links that exist between basic and clinical aspects relevant to light treatment in psychiatry. Moreover, recent studies on BLT in SAD and other mood disorders will be discussed together with new findings concerning the mode of action of BLT, wavelength, intensity, and the so-called placebo problem in light-therapy studies.

\section{KARGER}

Fax +4161306 1234

E-Mail karger@karger.ch

www.karger.com
(C) 2011 S. Karger AG, Basel

0302-282X/11/0643-0152\$38.00/0

Accessible online at:

www.karger.com/nps
Siegfried Kasper, MD

Department of Psychiatry and Psychotherapy

Medical University of Vienna, Währinger Gürtel 18-20

AT-1090 Vienna (Austria)

Tel. +43 140400 3568, E-Mail sci-biolpsy@meduniwien.ac.at 


\section{Circadian and Seasonal Adaptive Mechanisms and Their Disturbances in Mood Disorders}

\section{The Suprachiasmatic Nucleus}

Almost all physiological functions of the body, like secretion patterns of hormones, sleep-wake cycle or core body temperature, follow specific rhythmic changes throughout the day [13]. These highly specialized functions are driven by the master clock, the suprachiasmatic nucleus (SCN), and can be seen as the core of an adaptive system reacting to predictable everyday demands of life. The SCN consists of approximately 10,000 neurons located within the anterior hypothalamus and allows mammals, including humans, to maintain this circadian cycle in body functions, even when totally isolated from zeitgebers [14]. This function is lost if the SCN is destroyed [15]. The circadian system is primarily entrained by the zeitgeber light. Information on the light-dark cycle is perceived and transduced by melanopsin-containing retinal cells [16]. These cells are directly connected to the SCN via the retinohypothalamic tract and are not part of the visual system. Entrainment depends on time of presentation, duration, wavelength and dose of light [17]. In addition, the SCN is modulated by serotonergic neurons originating in the raphe nuclei [18]. The SCN receives direct feedback from the pineal gland via $\mathrm{MT}_{1}$ and $\mathrm{MT}_{2}$ melatonin receptors $[19,20]$. However, the majority of cells in the human organism follow their own circadian rhythms and zeitgebers. These rhythms are synchronized with the primary oscillator, SCN, to a varying extent [21-23].

\section{Melatonin}

Melatonin (N-acetyl-5-methoxytryptamine), a central hormone of internal clock circuitries [24], was first identified by Lerner et al. [25] in 1958. It is secreted primarily by the pineal gland in a specific circadian pattern in accordance with the light-dark cycle (high at night, low during the day) [26] and the seasonal cycle (longer peak in winter, shorter peak in summer) [27, 28]. Melatonin is synthesized from its precursor serotonin before it is rapidly distributed within the body [29]. The pace of secretion is controlled by the SCN and its main efferent pathway to the paraventricular nucleus through polysynaptic pathways of the sympathetic nervous system [30, 31]. Melatonin works as a biochemical marker transducing photoperiodic information and signalling seasonal variations of the light-dark cycle to all cells [32]. Peripheral effects of the circadian system are mainly mediated by the paraventricular nucleus and corticotropin-releasing factor secreting neurons enhancing periodical adaptation of body functions in anticipa- tion of diurnally varying requirements [33]. In 1980, Lewy et al. [24] were able to show that exposure to light had the potential to alter circadian rhythms and to suppress the secretion of melatonin in humans.

\section{Serotonin}

The predominant role of serotonin (5-hydroxytryptamine) in modulating behaviour, emotions, and circadian rhythms [31] made it one of the best-researched transmitters in the human brain. Serotonergic neurons originate in the raphe nuclei of the brainstem. A number of studies showed seasonal changes in serotonergic parameters, including brain serotonin concentration and turnover [3438]. Furthermore, serotonin-related behaviours change with the seasons in clinical and non-clinical populations [34, 39-47]. The most important physiological mechanism controlling synaptic serotonin levels is reuptake of serotonin into the presynaptic neuron via the serotonin transporter (5-HTT) [48, 49]. High 5-HTT density is associated with low extracellular serotonin, and vice versa [50]. In a study in healthy subjects, Praschak-Rieder et al. [51] have recently shown that 5-HTT binding in the living human brain varies with the season, with peak differences being as high as $40 \%$. 5-HTT binding potential values, an index of 5-HTT density, varied along a sinusoidal curve in all investigated brain regions during the course of the year. The highest 5-HTT binding potential values occurred during the dark months in autumn and winter, while the lowest values were found around the summer solstice. Moreover, 5-HTT binding potential values were negatively correlated with the duration of daily sunshine, with reductions in 5-HTT binding parallelling the increase in sunlight during spring. These results are in line with findings on the impact of light on serotonergic processing in rodents [52-56] and they offer a potential explanation for the regular reoccurrence of depressive episodes in patients with SAD and for the spring peak in suicide rates found in temperate and polar zones [57-61].

\section{Chronobiology of Mood Disorders}

Alterations of circadian rhythms in mood disorders can be classified into three groups: shift of phase (phase advance, phase delay), diminution of amplitude, and dayto-day variability to entrainment $[62,63]$. Typical changes of circadian rhythms in depression apply to sleep [64-68], hormones [69-78], and core body temperature [78-83], and results from a large meta-analysis of psychopathological symptoms of circadian rhythm disorders were able to distinguish depressed patients from normal controls $[78,84]$. Although chronobiological abnormali- 
Table 1. Diagnostic criteria of the seasonal pattern specifier according to the Diagnostic and Statistical Manual of Mental disorders, ed. 4, text revision adapted from ref. 87

A Regular temporal relationship between the onset of major depressive episodes and a particular time of the year (unrelated to obvious season-related psychological stressors)

B Full remission (or change from depression to mania or hypomania) also occurs at a characteristic time of the year

C Two major depressive episodes meeting criteria A and B in the last 2 years and no non-seasonal episodes in the same period

D Seasonal major depressive episodes substantially outnumber non-seasonal episodes over the individual's lifetime

ties in major depression are highly variable, the most characteristic chronobiological abnormality in depression is presumably phase advance [85].

\section{Seasonal Affective Disorder}

SAD can be seen as a model disorder for chronobiological disturbances and BLT. A first milestone was set by Rosenthal et al. [1], who characterized a subset of patients suffering from annually recurrent depressive episodes followed by spontaneous remission. Before this report, Lewy et al. [86] had published a case report of a bipolar patient with seasonal mood cycles. Today, the Diagnostic and Statistical Manual IV, text revision (DSM-IV-TR), lists SAD as a specifier of recurrent unipolar or bipolar affective disorders with a seasonal pattern of major depressive episodes [87]. The four central clinical features characterizing SAD are summarized in table 1. Winter depression, also termed fall-winter depression, constitutes the most common form of SAD [88]. In 1989, Kasper et al. [89] reported the occurrence of subsyndromal mood fluctuations in the general population. Since then, seasonality has been appraised as a dimensional process rather than a distinct syndrome by most authors. Patients suffering from SAD exhibit typical depressive symptoms like low mood, lack of drive, decrease in interest and lack of concentration [90]. In addition, patients tend to exhibit a specific symptom cluster related to atypical depression. These symptoms are hypersomnia (70-90\% of SAD patients), increased appetite (70-80\%), carbohydrate craving (8090\%) and weight gain (70-80\%) [91]. Furthermore, about three quarters of patients show increased irritability in fall/winter, and anger attacks seem to be especially preva- lent in SAD [91, 92]. Interestingly, almost half of the female patients with SAD suffer from premenstrual dysphoric disorder. Hence, a pathogenic connection between these two cyclic disorders has been proposed $[93,94]$. In epidemiological studies, the prevalence of SAD patients amounts to $2-5 \%$. The prevalence of the subsyndromal form of the disorder ranges between 5 and 10\%. SAD accounted for approximately $11 \%$ of all major depressive episodes in a Canadian community sample [95]. According to Winkler et al. [96], the female-to-male ratio in SAD $(3-5: 1)$ is even higher than in non-seasonal depression, where women are affected twice as often as men.

\section{Pathophysiology of SAD}

Chronobiological Hypothesis

In the literature, two main etiological pathways are discussed, which should be further illustrated: a chronobiological hypothesis and an altered monoaminergic transmission hypothesis [97].

The first hypothesis focuses on light and the circadian system, as previously presented in this review. Since it is evident that exposure to light is a matter of latitude, a number of studies tried to verify this assumption. However, while one large study [98] and one meta-analysis [99] came to the conclusion that there is a positive correlation between Northern latitude and prevalence of SAD, others failed to show such an association [100]. However, two putative explanations for negative results are migration, which allows vulnerable individuals to move to more temperate climate zones, and gene-environment interactions. Similarly, the data concerning the melatonergic system are not consistent. A number of studies provide evidence for abnormal melatonin levels in patients with SAD: high melatonin levels during daytime [101], prolonged nocturnal melatonin secretion in winter [102] and a phase delay of melatonin release [103]. However, there are also studies which could not discriminate between patients and healthy controls on the basis of melatonin secretion patterns [104, 105]. The phase shift hypothesis is nonetheless remarkable as many SAD patients are phase delayed in their chronobiological cycle. Morning BLT, as a strong external zeitgeber, is able to restore this disruption [106-108].

\section{Role of Monoamines}

The second hypothesis, the pathophysiological role of monoamines in SAD needs further consideration. As mentioned before, there is substantial evidence for a seasonal fluctuation in brain serotonin function $[37,51]$. Recently, an enhanced 5-HTT turnover rate (defined as the number of uptake events of one 5-HTT molecule per sec- 
ond) in platelets of medication-free depressed patients with SAD could be demonstrated by Willeit et al. [109]. One of the rare brain-imaging studies in SAD, also published by Willeit et al. [110], using $\left[{ }^{123} \mathrm{I}\right]-\beta$-CIT single-photon emission tomography showed decreased 5-HTT availability in the thalamus/hypothalamus of patients during winter depressive episodes. This finding could be replicated in patients suffering from non-seasonal atypical depression [111]. Further evidence for the role of serotonin in SAD, and the mode of action of BLT, comes from studies by Neumeister et al. [112], showing a depressive relapse in BLT-treated, remitted patients during depletion of the serotonin precursor tryptophan. Similar findings were also detected in patients with SAD during stable summer remission [113], although these results could not be replicated in another study [114]. However, two catecholamine depletion studies in BLT-treated remitted patients [115] and patients during summer remission [116] suggest a possible role of norepinephrine and dopamine in the pathophysiology of SAD. A number of genetic studies aimed at investigating vulnerabilities to SAD and seasonality. Most studies focused on the 5-HTT-linked polymorphic region (5-HTTLPR, SLC6A4) described two [117] or three [118] common functional polymorphisms. Results from a study by Caspi et al. [119] indicate that the 5HTTLPR short (s) allele, in contrast to the long $(l)$ allele, is associated with depressive episodes and suicidal behaviour after traumatic life events. However, a recent metaanalysis questioned the finding of a gene-environment interaction of 5-HTTLPR genotype and traumatic life events [120]. Findings in SAD are contradictory as well: while two earlier studies found associations between 5HTTLPR and SAD/seasonality [121, 122], a large metaanalysis yielded negative results [123]. Another SAD study found evidence for an association of 5-HTTLPR with atypical and melancholic depression subtypes, suggesting that the low-expressing 5-HTTLPR $s$-allele is associated with atypical symptoms rather than with a diagnosis of SAD [124]. The association of the 5-HTTLPR $s$-allele and the atypical depression subtype could be replicated in patients with non-seasonal depression [125].

\section{Bright-Light Therapy}

Today, the administration of BLT is the first-line therapy for SAD [126]. BLT represents a potent, non-pharmacological treatment modality whose efficacy and tolerability have been a matter of extensive research. Mode of action and administration of BLT will be addressed first.

\section{Mode of Action}

The exact mechanism of action of BLT remains unclear. The effect of BLT seems to be mediated through the eyes: extraocular administration has failed to show any significant antidepressant qualities [127]. Studies in the 1990s became the basis of a widely cited benchmark for BLT with light intensities of up to 10,000 $\mathrm{lx}$ and a duration of $30 \mathrm{~min} /$ day [128-130]. However, melanopsin, a shortwavelength light-sensitive G-protein-coupled receptor located in human retinal ganglion cells, is known to transduce short-wavelength light signals into neural signals [131]. Since melanopsin is primarily responsible for resetting the timing of the SCN, suppressing pineal melatonin secretion, and improving alertness and electroencephalogram-derived correlates of arousal [16, 132], it has been hypothesized that short-wavelength light with a low light intensity might be a better stimulator for melanopsin-containing retinal ganglion cells and the behaviours mediated via this photoreceptor system $[133,134]$. In a study by Anderson et al. [134], blue-appearing light at 98 $\mathrm{lx}$ was compared to blue-enriched white-appearing light at $700 \mathrm{~lx}$ in patients with SAD. Both light sources emitted fewer lux than traditional BLT sources, but emitted equivalent numbers of photons within the short-wavelength range. Depression rates decreased significantly in both groups after 3 weeks. However, this study was underpowered and did not include a non-treatment group. Another study tested short-wavelength blue light against short-wavelength red light (an intended placebo) with promising results for the blue-light condition [135]. However, since these studies did not compare blue light to standardized BLT with high-intensity white light at $10,000 \mathrm{~lx}$, low-intensity light is not established as uniquely effective in the treatment of SAD.

Whether the antidepressant effect of light is also related to its alerting property is unclear [136]. However, the acute alerting and performance-enhancing effects of light are increasingly taken into account for the design of indoor light standards in office environments $[133,137]$.

\section{Administration}

Commonly, BLT is applied using a light box containing fluorescent lamps, a reflector and a diffusing screen. There are different models with varying light intensities available on the market [88]. Further application forms are light visors and dawn simulators, both of which are not widely used. Light visors (or helmets) are portable head-mounted light sources $[138,139]$, a dawn simulator offers morning-light stimulation simulating natural dawn conditions [140]. For adequate treatment conditions, light 
Table 2. BLT guidelines adapted from ref. 88, 90

\begin{tabular}{|c|c|}
\hline Parameter & Information \\
\hline $\begin{array}{l}\text { Intensity of } \\
\text { bright-light device }\end{array}$ & $\begin{array}{l}\text { Fluorescent light box using light intensities } \\
\text { from } 5,000 \text { to } 10,000 \mathrm{~lx} \text { (measured at the } \\
\text { level of the eyes of the patient) }\end{array}$ \\
\hline $\begin{array}{l}\text { Wavelength of } \\
\text { bright-light device }\end{array}$ & Full-spectrum visible light \\
\hline $\begin{array}{l}\text { Distance from light } \\
\text { source }\end{array}$ & $\begin{array}{l}\text { Patients should remain positioned at } \\
\text { approximately } 60-80 \mathrm{~cm} \text { from the light } \\
\text { source } \\
\text { Staring into the light source is not necessary }\end{array}$ \\
\hline $\begin{array}{l}\text { Time of day } \\
\text { for application }\end{array}$ & $\begin{array}{l}\text { Morning light therapy is more effective } \\
\text { than evening light } \\
\text { However, in some patients evening light } \\
\text { therapy may be more successful }\end{array}$ \\
\hline Dose & $\begin{array}{l}30 \text { min at } 10,000 \mathrm{~lx} \text { or } 2 \mathrm{~h} \text { at } 2,500 \mathrm{~lx} \text { as a } \\
\text { starting dose }\end{array}$ \\
\hline $\begin{array}{l}\text { Onset of } \\
\text { therapeutic effect }\end{array}$ & 3-7 days \\
\hline $\begin{array}{l}\text { Maintenance of } \\
\text { therapeutic effect }\end{array}$ & $\begin{array}{l}\text { Effect will vanish shortly after } \\
\text { discontinuation of therapy }\end{array}$ \\
\hline $\begin{array}{l}\text { In case of } \\
\text { non-response }\end{array}$ & $\begin{array}{l}\text { Application of double dose, administerred } \\
\text { in the morning and evening } \\
\text { Consider psychopharmacological treatment }\end{array}$ \\
\hline
\end{tabular}

intensities of 5,000-10,000 lx, measured at the level of the eyes, and a therapeutic distance of $60-80 \mathrm{~cm}$ from the light box can be seen as standard requirements [141].

At this point, it is important to mention that patients need not stare directly into the light source as long as the light is able to meet the eye at an angle of $30-60^{\circ}$. Treatment is started with a dose of 30 min using a light intensity of 10,000 lx, the duration of treatment is extended in case of insufficient response [142]. When using less powerful light boxes, the exposition time should be extended [90]. Morning administration of BLT offers greater chances for remission as pointed out in the following section.

However, compliance is the primary factor of success of the treatment, and extensive information and clear instructions concerning utilization and duration of BLT should be provided. According to a small pilot study by Michalak et al. [143], patients' adherence to a set light treatment regimen is as important as adherence to antidepressant medication. The effects of treatment do not persist after discontinuation of BLT, thus a relapse can be anticipated few days after stopping the treatment. Some SAD patients may profit from a prophylactic initiation of BLT $[144,145]$. In this context, psycho-educational training for the detection of early symptoms (difficulties in awakening, daytime fatigue and carbohydrate craving) may help to prevent the onset of a full-blown episode of SAD. Useful tools for maintaining the patients' cooperation are a stringent therapeutic setting with frequent clinical assessments and constant patients' reports about exposure time and psychopathological status. For clinical trials as well as daily practice, the Structured Interview for the Hamilton Depression Rating Scale - Seasonal Affective Disorder Version (SIGH-SAD) has been implemented to cover the specific symptom cluster of SAD [146]. It consists of the 21 items of the Hamilton Depression Rating Scale [147], 8 additional items characterizing atypical depressive symptoms and 2 unscored items assessing difficulties in awakening and temperature discomfort [126]. A summary of application principles is presented in table 2 .

\section{Light Therapy in SAD and Non-Seasonal Mood \\ Disorders}

When assessing the efficacy of BLT, researchers encounter obvious obstacles in developing study designs. While it is relatively simple to produce placebos for randomized and controlled psychopharmacological trials, developing a placebo for BLT led to controversies in the scientific community. During the 1980s, the usual placebo condition was a light box delivering intensities of $\leq 300 \mathrm{~lx}$, often of a different color. These studies were criticized by some authors with regard to the adequacy of the control condition. Although a pooled analysis of these data showed that BLT is superior to dim light controls, expectations of the subjects sometimes predicted the clinical outcome.

Other studies used negative-ion generators as placebo condition, a device that similarly to a light box requires the patient to sit next to it. The superiority of both morning and evening BLT over low-density negative air ionization, or sham negative air ionization, respectively, as placebo conditions could be demonstrated in two large studies using a balanced, randomized cross-over design [148, 149]. These findings from two independent centres are remarkable in so far as the advantage of antidepressant drugs over placebo in controlled trials is so small that only multicenter studies can answer questions of relevance [150]. Surprisingly, high doses, but not low doses, of negative air ions were found to have an antidepressant effect as well [151]. In both studies, expectation ratings within groups were not correlated with clinical response.

The most recent meta-analysis on the efficacy of BLT was published by Golden et al. [152] in 2005, following a 
request of the American Psychiatric Association in order to systematically gather efficacy data following the principles of evidence-based medicine. The authors initiated a systematic review of all existing data of trials using BLT in seasonal and non-seasonal depression, using dawn simulation for SAD and using BLT as adjunctive therapy to psychopharmacological treatment in non-seasonal depression. Twenty-three of 173 studies qualified for inclusion (age 18-65, DSM diagnosis, Rosenthal criteria, standardized BLT conditions, plausible and defined placebo conditions) into the meta-analysis. Results show impressive effect sizes, i.e. 0.84 (CI 95\%: 0.60-1.08) for BLT in SAD, 0.73 (CI 95\%: 0.37-1.08) for dawn simulation in SAD and 0.53 (CI 95\%: 0.18-0.89) for BLT in non-seasonal depression. These effect sizes are equivalent or superior to most psychopharmacological trials. In the metaanalysis, there was no evidence in favour of adjunctive BLT to psychopharmacological treatment in non-seasonal depression. However, there are also positive data from a subsequent placebo-controlled randomized trial of BLT augmentation in a sample of 102 patients with non-seasonal depression treated with sertraline [153].

In a review of 332 patients with SAD from 14 different study centres, Terman et al. [154] found remission rates of up to $67 \%$ in patients suffering from milder depression, and up to $40 \%$ in patients with severe depression. Moreover, the latter review could substantiate a faster onset of action of BLT compared to treatment with antidepressants.

Three studies published in 1998 were able to conclusively demonstrate that early morning administration of BLT is associated with higher remission rates than evening administration. Nevertheless, a small subset of patients preferentially benefited from evening light $[149,151$, 155]. One explanation for this is that, according to the phase shift hypothesis, there are two kinds of internal circadian misalignment in SAD: while the typical depressed patient is phase-delayed, a small subgroup of phase-advanced patients may preferentially benefit from a corrective phase delay provided by evening BLT $[156,157]$.

Patients with bipolar depression have been shown to respond robustly to BLT [158]. Response rates did not differ significantly between bipolar and unipolar patients with SAD [159]. Another study found non-seasonally depressed bipolar patients to improve more with BLT than unipolar depressed patients [160]. These data suggest that BLT is a valuable treatment modality in bipolar-depressed patients. Like other biological treatments for bipolar depression, BLT can precipitate manic/hypomanic and mixed states in susceptible patients [161-163], although the potential advantage of BLT in patients with bipolar
Table 3. Indications for psychopharmacological treatment in SAD adapted from ref. 88

Patient's choice

Missing compliance using BLT

Non-response to BLT

Adverse reactions to BLT

Ophthalmological contraindications (e.g. macular degeneration)

Bipolar disorder (switch to hypomania/mania)

Severe depression (e.g. psychotic depression)

Suicide risk (consider hospitalization)

depression is that the light dose can be titrated against emergent symptoms of hypomania. However, as of yet, there are no specific BLT guidelines for patients with bipolar disorder other than the need for additional antimanic-agent coverage. In a small dose-ranging safety and efficacy study in depressed women with bipolar disorder, 3 of 4 subjects treated with morning BLT developed mixed states [164]. This was not the case in subjects receiving midday light. The authors conclude that women with bipolar depression may be highly sensitive to morning BLT, and that initiating treatment with a brief course of midday light is advisable. Another recent study in patients with non-seasonal bipolar depression could demonstrate that a chronotherapeutic intervention with one night of sleep deprivation, BLT, and sleep phase advance as adjunctive treatment to lithium and antidepressants lead to accelerated and sustained antidepressant responses when compared to a medication-only group [165].

BLT has also been found to be effective in chronic depression [166]. Preliminary studies of BLT in antepartum depression, a condition where non-pharmacological treatment options are urgently needed, show promising results $[167,168]$. In non-seasonal depression, BLT is sometimes combined with other chronotherapeutic interventions (wake therapy and phase changes of sleep) because they are hypothesized to act through complementary mechanisms [169-171]. Neumeister et al. [172] were the first to show that morning BLT can help maintaining the antidepressant effects of therapeutic sleep deprivation, a finding which could be replicated in a number of subsequent studies $[158,173]$. There are few data on BLT in premenstrual dysphoric disorder. Results of these studies remain controversial [94, 174, 175].

In case of non-response, side effects or patients' inability to integrate BLT into their daily routine psychopharmacological treatment, preferably using an antidepressant with serotonergic or noradrenergic properties, is in- 
dicated $[88,176]$. Reviewing clinical courses of 553 SAD patients, Pjrek et al. [177] found that $49 \%$ of patients were receiving psychotropic medication, with $35.4 \%$ being treated with an antidepressant drug. Indications for psychopharmacological treatment in the context of BLT are summarized in table 3 .

\section{Safety and Tolerability of BLT}

Generally, BLT is well tolerated and well accepted by patients [99]. Side effects are rare; the most common ones are headache, eyestrain, nausea and agitation. Side effects tend to remit spontaneously or after dose reduction [178, 179]. Evening administration of BLT can increase the incidence of sleep disturbances; bipolar patients may switch to hypomania during therapy [180]. Suicidality may sporadically occur early in the treatment course [181, 182], menstrual irregularities have been reported [183]. Although there is some evidence for retinal degeneration after prolonged exposure to intensive visible light in rodents [184], this was not confirmed in humans [185].
However, patients with a (family) history of retinal damage or patients needing photosensitizing medication are advised to consult their ophthalmologist before initiating treatment. In any case, UV light must be avoided.

\section{Conclusion}

BLT represents a non-pharmacological, efficacious, well-tolerated, well-accepted and probably underestimated biological therapy which should be part of the therapeutic repertoire of all psychiatrists and general practitioners. There is no solid medical reason for nonreimbursement of BLT for all patients profiting from it. Ideally, light boxes should primarily be lent to patients by physicians and health care professionals in order to assess diagnosis and treatment response. Consequently, patients with beneficial treatment responses ought to have fair access to BLT similarly to psychopharmacological treatment.

\section{References}

$>1$ Rosenthal NE, Sack DA, Gillin JC, Lewy AJ, Goodwin FK, Davenport Y, Mueller PS, Newsome DA, Wehr TA: Seasonal affective disorder. A description of the syndrome and preliminary findings with light therapy. Arch Gen Psychiatry 1984;41:72-80.

$\checkmark 2$ Horowitz TS, Tanigawa T: Circadian-based new technologies for night workers. Ind Health 2002;40:223-236.

-3 Burgess HJ, Sharkey KM, Eastman CI: Bright light, dark and melatonin can promote circadian adaptation in night shift workers. Sleep Med Rev 2002;6:407-420.

4 Graf A, Wallner C, Schubert V, Willeit M, Wlk W, Fischer P, Kasper S, Neumeister A: The effects of light therapy on mini-mental state examination scores in demented patients. Biol Psychiatry 2001;50:725-727.

5 Ancoli-Israel S, Martin JL, Kripke DF, Marler M, Klauber MR: Effect of light treatment on sleep and circadian rhythms in demented nursing home patients. J Am Geriatr Soc 2002;50:282-289.

-6 Terman M, Lewy AJ, Dijk DJ, Boulos Z, Eastman CI, Campbell SS: Light treatment for sleep disorders: consensus report. IV. Sleep phase and duration disturbances. J Biol Rhythms 1995;10:135-147.

7 Montgomery P, Dennis J: Bright light therapy for sleep problems in adults aged $60+$. Cochrane Database Syst Rev 2002:CD003403.

$>8$ Lam RW, Goldner EM, Solyom L, Remick RA: A controlled study of light therapy for bulimia nervosa. Am J Psychiatry 1994;151: $744-750$.
$>9$ Lam RW, Lee SK, Tam EM, Grewal A, Yatham LN: An open trial of light therapy for women with seasonal affective disorder and comorbid bulimia nervosa. J Clin Psychiatry 2001;62:164-168.

10 Braun DL, Sunday SR, Fornari VM, Halmi KA: Bright light therapy decreases winter binge frequency in women with bulimia nervosa: a double-blind, placebo-controlled study. Compr Psychiatry 1999;40:442-448.

11 Blouin AG, Blouin JH, Iversen H, Carter J, Goldstein C, Goldfield G, Perez E: Light therapy in bulimia nervosa: a double-blind, placebo-controlled study. Psychiatry Res 1996;60:1-9.

12 Rybak YE, McNeely HE, Mackenzie BE, Jain UR, Levitan RD: An open trial of light therapy in adult attention-deficit/hyperactivity disorder. J Clin Psychiatry 2006;67:15271535.

13 Monteleone P, Maj M: The circadian basis of mood disorders: recent developments and treatment implications. Eur Neuropsychopharmacol 2008;18:701-711.

14 Hastings MH: Central clocking. Trends Neurosci 1997;20:459-464.

15 Klein DC, Moore RY, Reppert SM: Suprachiasmatic Nucleus: the Mind's Clock. Oxford University Press, 1991.

16 Hattar S, Lucas RJ, Mrosovsky N, Thompson S, Douglas RH, Hankins MW, Lem J, Biel M, Hofmann F, Foster RG, Yau KW: Melanopsin and rod-cone photoreceptive systems account for all major accessory visual functions in mice. Nature 2003;424:76-81.
17 Zeitzer JM, Khalsa SB, Boivin DB, Duffy JF, Shanahan TL, Kronauer RE, Czeisler CA: Temporal dynamics of late-night photic stimulation of the human circadian timing system. Am J Physiol Regul Integr Comp Physiol 2005;289:R839-R844.

18 Moore RY, Speh JC: Serotonin innervation of the primate suprachiasmatic nucleus. Brain Res 2004;1010:169-173.

19 Stehle JH, von Gall C, Korf HW: Melatonin: a clock-output, a clock-input. J Neuroendocrinol 2003;15:383-389.

20 Macchi MM, Bruce JN: Human pineal physiology and functional significance of melatonin. Front Neuroendocrinol 2004;25:177195

21 Schibler U, Ripperger J, Brown SA: Peripheral circadian oscillators in mammals: time and food. J Biol Rhythms 2003;18:250-260.

$\checkmark 22$ Buijs RM, Kalsbeek A: Hypothalamic integration of central and peripheral clocks. Nat Rev Neurosci 2001;2:521-526.

23 Wirz-Justice A: Biological rhythm disturbances in mood disorders. Int Clin Psychopharmacol 2006;21(suppl 1):S11-S15.

24 Lewy AJ, Wehr TA, Goodwin FK, Newsome DA, Markey SP: Light suppresses melatonin secretion in humans. Science 1980;210:12671269.

25 Lerner AB, Case JD, Takahashi Y, Lee TH, Mori N: Isolation of melatonin, a pineal factor that lightens melanocytes. J Am Chem Soc $1958 ; 80: 2587$. 
-26 Pandi-Perumal SR, Trakht I, Srinivasan V, Spence DW, Maestroni GJ, Zisapel N, Cardinali DP: Physiological effects of melatonin: role of melatonin receptors and signal transduction pathways. Prog Neurobiol 2008;85: 335-353.

-27 Morgan PJ, Barrett P, Howell HE, Helliwell $\mathrm{R}$ : Melatonin receptors: localization, molecular pharmacology and physiological significance. Neurochem Int 1994;24:101-146.

28 Wehr TA: The durations of human melatonin secretion and sleep respond to changes in daylength (photoperiod). J Clin Endocrinol Metab 1991;73:1276-1280.

29 Cardinali DP, Pevet P: Basic aspects of melatonin action. Sleep Med Rev 1998;2:175-190.

- 30 Liebmann PM, Wolfler A, Felsner P, Hofer D, Schauenstein K: Melatonin and the immune system. Int Arch Allergy Immunol 1997;112: 203-211.

31 Purves D: Neuroscience, ed 4. Chapter Sleep and Wakefulness. Sinauer Associates Inc. Publishers, Massachusetts 2004.

- 32 Simonneaux V, Ribelayga C: Generation of the melatonin endocrine message in mammals: a review of the complex regulation of melatonin synthesis by norepinephrine, peptides, and other pineal transmitters. Pharmacol Rev 2003;55:325-395.

-33 Abuja PM, Liebmann P, Hayn M, Schauenstein $\mathrm{K}$, Esterbauer $\mathrm{H}$ : Antioxidant role of melatonin in lipid peroxidation of human ldl. FEBS Lett 1997;413:289-293.

-34 Callaway J, Storvik M, Halonen P, Hakko H, Rasanen P, Tiihonen J: Seasonal variations in $[3 \mathrm{H}]$ citalopram platelet binding between healthy controls and violent offenders in Finland. Hum Psychopharmacol 2005;20: 467-472.

- 35 Maes M, Scharpe S, Verkerk R, D’Hondt P, Peeters D, Cosyns P, Thompson P, De Meyer F, Wauters A, Neels H: Seasonal variation in plasma l-tryptophan availability in healthy volunteers. Relationships to violent suicide occurrence. Arch Gen Psychiatry 1995;52: 937-946.

- 36 Sarrias MJ, Artigas F, Martinez E, Gelpi E: Seasonal changes of plasma serotonin and related parameters: correlation with environmental measures. Biol Psychiatry 1989; 26:695-706.

37 Carlsson A, Svennerholm L, Winblad B: Seasonal and circadian monoamine variations in human brains examined post mortem. Acta Psychiatr Scand Suppl 1980;280:75-85.

- 38 Lambert GW, Reid C, Kaye DM, Jennings GL, Esler MD: Effect of sunlight and season on serotonin turnover in the brain. Lancet 2002;360:1840-1842.

- 39 Kasper S, Wehr TA, Bartko JJ, Gaist PA, Rosenthal NE: Epidemiological findings of seasonal changes in mood and behavior. A telephone survey of montgomery county, maryland. Arch Gen Psychiatry 1989;46: 823-833.

-40 Hardin TA, Wehr TA, Brewerton T, Kasper S, Berrettini W, Rabkin J, Rosenthal NE: Evaluation of seasonality in six clinical populations and two normal populations. J Psychiatr Res 1991;25:75-87.
41 Harris S, Dawson-Hughes B: Seasonal mood changes in 250 normal women. Psychiatry Res 1993;49:77-87.

42 Okawa M, Shirakawa S, Uchiyama M, Oguri M, Kohsaka M, Mishima K, Sakamoto K, Inoue H, Kamei K, Takahashi K: Seasonal variation of mood and behaviour in a healthy middle-aged population in Japan. Acta Psychiatr Scand 1996;94:211-216.

43 Hegde AL, Woodson H: Prevalence of seasonal changes in mood and behavior during the winter months in central Texas. Psychiatry Res 1996;62:265-271.

44 Rohan KJ, Sigmon ST: Seasonal mood patterns in a northeastern college sample. J Affect Disord 2000;59:85-96.

45 Perry JA, Silvera DH, Rosenvinge JH, Neilands T, Holte A: Seasonal eating patterns in norway: a non-clinical population study. Scand J Psychol 2001;42:307-312.

46 Chotai J, Smedh K, Johansson C, Nilsson LG, Adolfsson R: An epidemiological study on gender differences in self-reported seasonal changes in mood and behaviour in a general population of northern sweden. Nord J Psychiatry 2004;58:429-437.

47 Friedman E, Gyulai L, Bhargava M, Landen $\mathrm{M}$, Wisniewski S, Foris J, Ostacher M, Medina R, Thase M: Seasonal changes in clinical status in bipolar disorder: a prospective study in 1000 STEP-BD patients. Acta Psychiatr Scand 2006;113:510-517.

48 Rudnick G, Clark J: From synapse to vesicle: the reuptake and storage of biogenic amine neurotransmitters. Biochim Biophys Acta 1993;1144:249-263.

49 Ramamoorthy S, Bauman AL, Moore KR, Han H, Yang-Feng T, Chang AS, Ganapathy V, Blakely RD: Antidepressant- and cocainesensitive human serotonin transporter: Molecular cloning, expression, and chromosomal localization. Proc Natl Acad Sci USA 1993;90:2542-2546.

-50 Jennings KA, Loder MK, Sheward WJ, Pei Q, Deacon RM, Benson MA, Olverman HJ, Hastie ND, Harmar AJ, Shen S, Sharp T: Increased expression of the 5-HT transporter confers a low-anxiety phenotype linked to decreased 5-HT transmission. J Neurosci 2006;26:8955-8964.

51 Praschak-Rieder N, Willeit M, Wilson AA, Houle S, Meyer JH: Seasonal variation in human brain serotonin transporter binding. Arch Gen Psychiatry 2008;65:1072-1078.

52 Penev PD, Zee PC, Turek FW: Serotonin in the spotlight. Nature 1997;385:123.

53 Rovescalli AC, Brunello N, Riva M, Galimberti R, Racagni G: Effect of different photoperiod exposure on [3H]imipramine binding and serotonin uptake in the rat brain. J Neurochem 1989;52:507-514.

54 Kennaway DJ, Moyer RW: Serotonin 5HT2c agonists mimic the effect of light pulses on circadian rhythms. Brain Res 1998;806: 257-270.

55 Moyer RW, Kennaway DJ, Ferguson SA, Dijstelbloem YP: Quipazine and light have similar effects on c-fos induction in the rat suprachiasmatic nucleus. Brain Res 1997; 765:337-342.
56 Moyer RW, Kennaway DJ: Serotonin depletion decreases light induced c-fos in the rat suprachiasmatic nucleus. Neuroreport 2000; 11:1021-1024.

57 Chew KS, McCleary R: The spring peak in suicides: a cross-national analysis. Soc Sci Med 1995;40:223-230.

58 Rocchi MB, Perlini C: Is the time of suicide a random choice? A new statistical perspective. Crisis 2002;23:161-166.

59 Partonen T, Haukka J, Viilo K, Hakko H, Pirkola S, Isometsa E, Lonnqvist J, Sarkioja T, Vaisanen E, Rasanen P: Cyclic time patterns of death from suicide in northern Finland. J Affect Disord 2004;78:11-19.

-60 Bjorksten KS, Bjerregaard P, Kripke DF: Suicides in the midnight sun - a study of seasonality in suicides in west Greenland. Psychiatry Res 2005; 133:205-213.

61 Parker G, Gao F, Machin D: Seasonality of suicide in singapore: data from the equator. Psychol Med 2001;31:549-553.

62 Van Cauter E, Turek FW: Depression: a disorder of timekeeping? Perspect Biol Med 1986;29:510-519.

63 Gorwood P: Depression and circadian rhythm disturbances. Medicographia 2007; 29:22-27.

64 Kupfer DJ: REM latency: a psychobiologic marker for primary depressive disease. Biol Psychiatry 1976;11:159-174.

-65 Ansseau M, Kupfer DJ, Reynolds CF 3rd, McEachran AB: REM latency distribution in major depression: clinical characteristics associated with sleep onset rem periods. Biol Psychiatry 1984;19:1651-1666.

66 Brunello N, Armitage R, Feinberg I, Holsboer-Trachsler E, Leger D, Linkowski P, Mendelson WB, Racagni G, Saletu B, Sharpley AL, Turek F, Van Cauter E, Mendlewicz J: Depression and sleep disorders: clinical relevance, economic burden and pharmacological treatment. Neuropsychobiology 2000; 42:107-119.

67 Ford DE, Kamerow DB: Epidemiologic study of sleep disturbances and psychiatric disorders. An opportunity for prevention? JAMA 1989;262:1479-1484.

68 Eaton WW, Badawi M, Melton B: Prodromes and precursors: epidemiologic data for primary prevention of disorders with slow onset. Am J Psychiatry 1995;152:967-972.

69 Claustrat B, Brun J, Chazot G: The basic physiology and pathophysiology of melatonin. Sleep Med Rev 2005;9:11-24.

70 Van Cauter E, Leproult R, Kupfer DJ: Effects of gender and age on the levels and circadian rhythmicity of plasma cortisol. J Clin Endocrinol Metab 1996;81:2468-2473.

71 Linkowski P, Mendlewicz J, Leclercq R, Brasseur M, Hubain P, Golstein J, Copinschi G, Van Cauter E: The 24-hour profile of adrenocorticotropin and cortisol in major depressive illness. J Clin Endocrinol Metab 1985;61: 429-438. 
-72 Linkowski P, Van Cauter E, Leclercq R, Desmedt D, Brasseur M, Golstein J, Copinschi G, Mendlewicz J: ACTH, cortisol and growth hormone 24-hour profiles in major depressive illness. Acta Psychiatr Belg 1985;85:615623.

-73 Mendlewicz J, Linkowski P, Kerkhofs M, Desmedt D, Golstein J, Copinschi G, Van Cauter E: Diurnal hypersecretion of growth hormone in depression. J Clin Endocrinol Metab 1985;60:505-512.

-74 Kijne B, Aggernaes H, Fog-Moller F, Andersen $\mathrm{HH}$, Nissen J, Kirkegaard C, Bjorum N: Circadian variation of serum thyrotropin in endogenous depression. Psychiatry Res 1982;6:277-282.

-75 Scheer FA, Czeisler CA: Melatonin, sleep, and circadian rhythms. Sleep Med Rev 2005; 9:5-9.

76 Beck-Friis J, Ljunggren JG, Thoren M, von Rosen D, Kjellman BF, Wetterberg L: Melatonin, cortisol and ACTH in patients with major depressive disorder and healthy humans with special reference to the outcome of the dexamethasone suppression test. Psychoneuroendocrinology 1985;10:173-186.

-77 Brown RP, Caroff S, Kocsis JH, Amsterdam J, Winokur A, Stokes P, Frazer A: Nocturnal serum melatonin in major depressive disorder before and after desmethylimipramine treatment. Psychopharmacol Bull 1985;21: 579-581.

-78 Souetre E, Salvati E, Belugou JL, Pringuey D, Candito M, Krebs B, Ardisson JL, Darcourt G: Circadian rhythms in depression and recovery: evidence for blunted amplitude as the main chronobiological abnormality. Psychiatry Res 1989;28:263-278.

-79 Avery DH, Wildschiodtz G, Rafaelsen OJ: Nocturnal temperature in affective disorder. J Affect Disord 1982;4:61-71.

-80 Tsujimoto T, Yamada N, Shimoda K, Hanada $\mathrm{K}$, Takahashi S: Circadian rhythms in depression. Part II. Circadian rhythms in inpatients with various mental disorders. J Affect Disord 1990;18:199-210.

-81 Dietzel M, Saletu B, Lesch OM, Sieghart W, Schjerve M: Light treatment in depressive illness. Polysomnographic, psychometric and neuroendocrinological findings. Eur Neurol 1986;25(suppl 2):93-103.

-82 Goetze U, Tolle R: Circadian rhythm of free urinary cortisol, temperature and heart rate in endogenous depressives and under antidepressant therapy. Neuropsychobiology 1987; 18:175-184.

83 Parry BL, Mendelson WB, Duncan WC, Sack DA, Wehr TA: Longitudinal sleep EEG, temperature, and activity measurements across the menstrual cycle in patients with premenstrual depression and in age-matched controls. Psychiatry Res 1989;30:285-303.

84 Benca RM, Obermeyer WH, Thisted RA, Gillin JC: Sleep and psychiatric disorders. A meta-analysis. Arch Gen Psychiatry 1992;49: 651-668; discussion 669-670.

85 Wirz-Justice A: Diurnal variation of depressive symptoms. Dialogues Clin Neurosci $2008 ; 10: 337-343$
86 Lewy AJ, Kern HA, Rosenthal NE, Wehr TA: Bright artificial light treatment of a manicdepressive patient with a seasonal mood cycle. Am J Psychiatry 1982;139:1496-1498.

87 American Psychiatric Association: Diagnostic and Statistical Manual of Mental Disorders, ed 4, text revision (DSM-IV-TR). Washington, American Psychiatric Press, 2000.

88 Winkler D, Pjrek E, Iwaki R, Kasper S: Treatment of seasonal affective disorder. Expert Rev Neurother 2006;6:1039-1048.

89 Kasper S, Rogers SL, Yancey A, Schulz PM, Skwerer RG, Rosenthal NE: Phototherapy in individuals with and without subsyndromal seasonal affective disorder. Arch Gen Psychiatry 1989;46:837-844.

90 Praschak-Rieder N, Willeit M: Treatment of seasonal affective disorder. Dialogues Clin Neurosci 2003;5:389-398.

91 Winkler D, Willeit M, Praschak-Rieder N, Lucht MJ, Hilger E, Konstantinidis A, Stastny J, Thierry N, Pjrek E, Neumeister A, Moller HJ, Kasper S: Changes of clinical pattern in seasonal affective disorder (SAD) over time in a German-speaking sample. Eur Arch Psychiatry Clin Neurosci 2002;252:5462.

92 Winkler D, Pirek E, Konstantinidis A, Praschak-Rieder N, Willeit M, Stastny J, Kasper $S$ : Anger attacks in seasonal affective disorder. Int J Neuropsychopharmacol 2006;9: 215-219.

93 Praschak-Rieder N, Willeit M, Neumeister A, Hilger E, Stastny J, Thierry N, Lenzinger E, Kasper S: Prevalence of premenstrual dysphoric disorder in female patients with seasonal affective disorder. J Affect Disord 2001;63:239-242.

94 Lam RW, Carter D, Misri S, Kuan AJ, Yatham LN, Zis AP: A controlled study of light therapy in women with late luteal phase dysphoric disorder. Psychiatry Res 1999;86:185-192.

95 Levitt AJ, Boyle MH, Joffe RT, Baumal Z: Estimated prevalence of the seasonal subtype of major depression in a Canadian community sample. Can J Psychiatry 2000;45:650654.

96 Winkler D, Praschak-Rieder N, Willeit M, Lucht MJ, Hilger E, Konstantinidis A, Stastny J, Thierry N, Pjrek E, Neumeister A, Moller HJ, Kasper S: Seasonal affective depression in 2 German-speaking university centers: Bonn, Vienna. Clinical and demographic characteristics (in German). Nervenarzt 2002;73:637-643

97 Levitan RD: The chronobiology and neurobiology of winter seasonal affective disorder. Dialogues Clin Neurosci 2007;9:315-324.

98 Rosen LN, Targum SD, Terman M, Bryant MJ, Hoffman H, Kasper SF, Hamovit JR, Docherty JP, Welch B, Rosenthal NE: Prevalence of seasonal affective disorder at four latitudes. Psychiatry Res 1990;31:131-144.

99 Michalak EE, Lam RW: Seasonal affective disorder: the latitude hypothesis revisited. Can J Psychiatry 2002;47:787-788.
100 Levitt AJ, Boyle MH: The impact of latitude on the prevalence of seasonal depression. Can J Psychiatry 2002;47:361-367.

101 Danilenko KV, Putilov AA, Russkikh GS, Duffy LK, Ebbesson SO: Diurnal and seasonal variations of melatonin and serotonin in women with seasonal affective disorder. Arctic Med Res 1994;53:137-145.

102 Wehr TA, Duncan WC Jr, Sher L, Aeschbach D, Schwartz PJ, Turner EH, Postolache TT, Rosenthal NE: A circadian signal of change of season in patients with seasonal affective disorder. Arch Gen Psychiatry 2001;58:1108-1114.

103 Dahl K, Avery DH, Lewy AJ, Savage MV, Brengelmann GL, Larsen LH, Vitiello MV, Prinz PN: Dim light melatonin onset and circadian temperature during a constant routine in hypersomnic winter depression. Acta Psychiatr Scand 1993;88:60-66.

104 Checkley SA, Murphy DG, Abbas M, Marks M, Winton F, Palazidou E, Murphy DM, Franey C, Arendt J: Melatonin rhythms in seasonal affective disorder. Br J Psychiatry 1993;163:332-337.

105 Partonen T, Vakkuri O, Lamberg-Allardt C, Lonnqvist J: Effects of bright light on sleepiness, melatonin, and 25-hydroxyvitamin $\mathrm{D}_{3}$ in winter seasonal affective disorder. Biol Psychiatry 1996;39:865-872.

106 Murray G, Michalak EE, Levitt AJ, Levitan RD, Enns MW, Morehouse R, Lam RW: Therapeutic mechanism in seasonal affective disorder: do fluoxetine and light operate through advancing circadian phase? Chronobiol Int 2005;22:937-943.

107 Murray G, Michalak EE, Levitt AJ, Levitan RD, Enns MW, Morehouse R, Lam RW: O sweet spot where art thou? Light treatment of seasonal affective disorder and the circadian time of sleep. J Affect Disord 2006;90: 227-231.

108 Winkler D, Pjrek E, Praschak-Rieder N, Willeit M, Pezawas L, Konstantinidis A, Stastny J, Kasper S: Actigraphy in patients with seasonal affective disorder and healthy control subjects treated with light therapy. Biol Psychiatry 2005;58:331-336.

109 Willeit M, Sitte HH, Thierry N, Michalek K, Praschak-Rieder N, Zill P, Winkler D, Brannath W, Fischer MB, Bondy B, Kasper $S$, Singer EA: Enhanced serotonin transporter function during depression in seasonal affective disorder. Neuropsychopharmacology 2008;33:1503-1513.

110 Willeit M, Praschak-Rieder N, Neumeister A, Pirker W, Asenbaum S, Vitouch O, Tauscher J, Hilger E, Stastny J, Brucke T, Kasper S: $\left[{ }^{123} \mathrm{I}\right]-\beta$-CIT SPECT imaging shows reduced brain serotonin transporter availability in drug-free depressed patients with seasonal affective disorder. Biol Psychiatry 2000;47:482-489.

1 Lehto S, Tolmunen T, Joensuu M, Saarinen PI, Vanninen R, Ahola P, Tiihonen J, Kuikka J, Lehtonen J: Midbrain binding of $\left[{ }^{123} \mathrm{I}\right]$ nor- $\beta$-CIT in atypical depression. Prog Neuropsychopharmacol Biol Psychiatry 2006;30:1251-1255. 
112 Neumeister A, Praschak-Rieder N, Besselmann B, Rao ML, Gluck J, Kasper S: Effects of tryptophan depletion on drug-free patients with seasonal affective disorder during a stable response to bright light therapy. Arch Gen Psychiatry 1997;54:133-138.

113 Neumeister A, Praschak-Rieder N, Hesselmann B, Vitouch O, Rauh M, Barocka A, Kasper S: Effects of tryptophan depletion in fully remitted patients with seasonal affective disorder during summer. Psychol Med 1998;28:257-264.

- 114 Lam RW, Bowering TA, Tam EM, Grewal A, Yatham LN, Shiah IS, Zis AP: Effects of rapid tryptophan depletion in patients with seasonal affective disorder in natural summer remission. Psychol Med 2000;30:7987.

115 Neumeister A, Turner EH, Matthews JR, Postolache TT, Barnett RL, Rauh M, Vetticad RG, Kasper S, Rosenthal NE: Effects of tryptophan depletion vs catecholamine depletion in patients with seasonal affective disorder in remission with light therapy. Arch Gen Psychiatry 1998;55:524-530.

- 116 Lam RW, Tam EM, Grewal A, Yatham LN: Effects of $\alpha$-methyl-para-tyrosine-induced catecholamine depletion in patients with seasonal affective disorder in summer remission. Neuropsychopharmacology 2001; 25:S97-S101.

-117 Lesch KP, Bengel D, Heils A, Sabol SZ, Greenberg BD, Petri S, Benjamin J, Muller CR, Hamer DH, Murphy DL: Association of anxiety-related traits with a polymorphism in the serotonin transporter gene regulatory region. Science 1996;274:15271531.

-118 Hu XZ, Lipsky RH, Zhu G, Akhtar LA, Taubman J, Greenberg BD, Xu K, Arnold PD, Richter MA, Kennedy JL, Murphy DL, Goldman D: Serotonin transporter promoter gain-of-function genotypes are linked to obsessive-compulsive disorder. Am J Hum Genet 2006;78:815-826.

-119 Caspi A, Sugden K, Moffitt TE, Taylor A, Craig IW, Harrington H, McClay J, Mill J, Martin J, Braithwaite A, Poulton R: Influence of life stress on depression: moderation by a polymorphism in the 5-HTT gene. Science 2003;301:386-389.

120 Risch N, Herrell R, Lehner T, Liang KY, Eaves L, Hoh J, Griem A, Kovacs M, Ott J, Merikangas KR: Interaction between the serotonin transporter gene (5-HTTLPR), stressful life events, and risk of depression: a meta-analysis. JAMA 2009;301:24622471.

-121 Rosenthal NE, Mazzanti CM, Barnett RL, Hardin TA, Turner EH, Lam GK, Ozaki N, Goldman D: Role of serotonin transporter promoter repeat length polymorphism (5-HTTLPR) in seasonality and seasonal affective disorder. Mol Psychiatry 1998;3: 175-177.
122 Sher L, Hardin TA, Greenberg BD, Murphy DL, Li Q, Rosenthal NE: Seasonality associated with the serotonin transporter promoter repeat length polymorphism. Am J Psychiatry 1999;156:1837.

123 Johansson C, Willeit M, Levitan R, Partonen T, Smedh C, Del Favero J, Bel Kacem S, Praschak-Rieder N, Neumeister A, Masellis M, Basile V, Zill P, Bondy B, Paunio T, Kasper S, Van Broeckhoven C, Nilsson LG, Lam R, Schalling M, Adolfsson R: The serotonin transporter promoter repeat length polymorphism, seasonal affective disorder and seasonality. Psychol Med 2003;33:785792.

124 Willeit M, Praschak-Rieder N, Neumeister A, Zill P, Leisch F, Stastny J, Hilger E, Thierry N, Konstantinidis A, Winkler D, Fuchs K, Sieghart W, Aschauer H, Ackenheil M, Bondy B, Kasper S: A polymorphism (5-HTTLPR) in the serotonin transporter promoter gene is associated with DSM-IV depression subtypes in seasonal affective disorder. Mol Psychiatry 2003;8: 942-946.

125 Baune BT, Hohoff C, Mortensen LS, Deckert J, Arolt V, Domschke K: Serotonin transporter polymorphism (5-HTTLPR) association with melancholic depression: a female specific effect? Depress Anxiety 2008;25:920-925.

126 Terman M, Terman JS: Light therapy for seasonal and nonseasonal depression: efficacy, protocol, safety, and side effects. CNS Spectr 2005;10:647-663; quiz 672.

127 Koorengevel KM, Gordijn MC, Beersma DG, Meesters Y, den Boer JA, van den Hoofdakker RH, Daan S: Extraocular light therapy in winter depression: a double-blind placebo-controlled study. Biol Psychiatry 2001;50:691-698.

128 Terman JS, Terman M, Schlager D, Rafferty B, Rosofsky M, Link MJ, Gallin PF, Quitkin FM: Efficacy of brief, intense light exposure for treatment of winter depression. Psychopharmacol Bull 1990;26:3-11.

129 Terman M, Amira L, Terman JS, Ross DC: Predictors of response and nonresponse to light treatment for winter depression. Am J Psychiatry 1996;153:1423-1429.

130 Partonen T: Effects of morning light treatment on subjective sleepiness and mood in winter depression. J Affect Disord 1994;30: 47-56.

131 Berson DM, Dunn FA, Takao M: Phototransduction by retinal ganglion cells that set the circadian clock. Science 2002;295: 1070-1073.

132 Peirson S, Foster RG: Melanopsin: another way of signaling light. Neuron 2006;49: 331-339.

133 Cajochen C: Alerting effects of light. Sleep Med Rev 2007;11:453-464.

134 Anderson JL, Glod CA, Dai J, Cao Y, Lockley SW: Lux vs. wavelength in light treatment of seasonal affective disorder. Acta Psychiatr Scand 2009;120:203-212.
35 Glickman G, Byrne B, Pineda C, Hauck WW, Brainard GC: Light therapy for seasonal affective disorder with blue narrowband light-emitting diodes (leds). Biol Psychiatry 2006;59:502-507.

136 Wirz-Justice A, Graw P, Kräuchi K, Haug H, Leonhardt G, Brunner D: Effect of light on unmasked circadian rhythms in winter depression. Oxford, Pergamon Press, 1993.

137 Aries MBC: Human lighting demands: healthy lighting in an office environment. Eindhoven, Eindhoven University Press, 2005, p 158.

138 Teicher MH, Glod CA, Oren DA, Schwartz PJ, Luetke C, Brown C, Rosenthal NE: The phototherapy light visor: more to it than meets the eye. Am J Psychiatry 1995;152: 1197-1202.

139 Joffe RT, Moul DE, Lam RW, Levitt AJ, Teicher MH, Lebegue B, Oren DA, Buchanan A, Glod CA, Murray MG, et al: Light visor treatment for seasonal affective disorder: a multicenter study. Psychiatry Res 1993;46: 29-39.

140 Leppamaki S, Meesters Y, Haukka J, Lonnqvist J, Partonen T: Effect of simulated dawn on quality of sleep - a communitybased trial. BMC Psychiatry 2003;3:14.

141 Konstantinidis A, Winkler D: Lichttherapie: Parameter und praktische Hinweise zur Anwendung. Herbst-/Winterdepression und Lichttherapie. Berlin, Springer, 2004, pp 133-144.

142 Lam RW, Levitt AJ: Canadian consensusguidelines for the treatment of SAD. A summary of the report of the Canadian consensus group on SAD. Vancouver, Clinical and Academic Publishing, 1999.

143 Michalak EE, Murray G, Wilkinson C, Dowrick C, Lam RW: A pilot study of adherence with light treatment for seasonal affective disorder. Psychiatry Res 2007;149: 315-320.

144 Partonen T, Lonnqvist J: Prevention of winter seasonal affective disorder by brightlight treatment. Psychol Med 1996;26: 1075-1080.

145 Meesters Y, Beersma DG, Bouhuys AL, van den Hoofdakker RH: Prophylactic treatment of seasonal affective disorder (SAD) by using light visors: bright white or infrared light? Biol Psychiatry 1999;46:239-246.

146 Williams JBW, Link MJ, Rosenthal NE: Structured interview guide for the Hamilton Depression Rating Scale - seasonal affective disorder version (SIGH-SAD). New York, New York State Psychiatric Institute, 2002.

147 Hamilton M: A rating scale for depression. J Neurol Neurosurg Psychiatry 1960;23: 56-62.

148 Eastman CI, Lahmeyer HW, Watell LG, Good GD, Young MA: A placebo-controlled trial of light treatment for winter depression. J Affect Disord 1992;26:211-221. 
149 Eastman CI, Young MA, Fogg LF, Liu L, 161 Chan PK, Lam RW, Perry KF: Mania preMeaden PM: Bright light treatment of winter depression: a placebo-controlled trial. Arch Gen Psychiatry 1998;55:883-889.

150 Wirz-Justice A: Beginning to see the light. Arch Gen Psychiatry 1998;55:861-862.

151 Terman M, Terman JS, Ross DC: A controlled trial of timed bright light and negative air ionization for treatment of winter depression. Arch Gen Psychiatry 1998;55: 875-882.

152 Golden RN, Gaynes BN, Ekstrom RD, Hamer RM, Jacobsen FM, Suppes T, Wisner KL, Nemeroff CB: The efficacy of light therapy in the treatment of mood disorders: a review and meta-analysis of the evidence. Am J Psychiatry 2005;162:656-662.

153 Martiny K, Lunde M, Unden M, Dam H, Bech P: Adjunctive bright light in non-seasonal major depression: results from clinician-rated depression scales. Acta Psychiatr Scand 2005;112:117-125.

- 154 Terman M, Terman JS, Quitkin FM, McGrath PJ, Stewart JW, Rafferty B: Light therapy for seasonal affective disorder. A review of efficacy. Neuropsychopharmacology 1989;2:1-22.

155 Lewy AJ, Bauer VK, Cutler NL, Sack RL, Ahmed S, Thomas KH, Blood ML, Jackson JM: Morning vs evening light treatment of patients with winter depression. Arch Gen Psychiatry 1998;55:890-896.

-156 Lewy AJ, Sack RL, Miller LS, Hoban TM: Antidepressant and circadian phase-shifting effects of light. Science 1987;235:352354.

157 Lewy AJ, Lefler BJ, Emens JS, Bauer VK: The circadian basis of winter depression. Proc Natl Acad Sci USA 2006;103:74147419.

158 Benedetti F, Barbini B, Fulgosi MC, Colombo C, Dallaspezia S, Pontiggia A, Smeraldi E: Combined total sleep deprivation and light therapy in the treatment of drug-resistant bipolar depression: acute response and long-term remission rates. J Clin Psychiatry 2005;66:1535-1540.

159 Lam RW, Zis AP, Goumeniouk AD: Somatic treatments for bipolar disorder; in Yatham LN, Kusumakar V, Kutcher SP (eds): Bipolar Disorder: A Clinician's Guide to Biological Treatments. Amsterdam, Harwood Academic Publishers, 2002, pp 246-263.

-160 Deltito JA, Moline M, Pollak C, Martin LY, Maremmani I: Effects of phototherapy on non-seasonal unipolar and bipolar depressive spectrum disorders. J Affect Disord 1991;23:231-237. cipitated by light therapy for patients with SAD. J Clin Psychiatry 1994;55:454.

162 Schwitzer J, Neudorfer C, Blecha HG, Fleischhacker WW: Mania as a side effect of phototherapy. Biol Psychiatry 1990;28:532534.

163 Kripke DF: Timing of phototherapy and occurrence of mania. Biol Psychiatry 1991;29: 1156-1157.

164 Sit D, Wisner KL, Hanusa BH, Stull S, Terman M: Light therapy for bipolar disorder: a case series in women. Bipolar Disord 2007;9:918-927.

165 Wu JC, Kelsoe JR, Schachat C, Bunney BG, Demodena A, Golshan S, Gillin JC, Potkin SG, Bunney WE: Rapid and sustained antidepressant response with sleep deprivation and chronotherapy in bipolar disorder. Biol Psychiatry 2009;66:298-301.

166 Goel N, Terman M, Terman JS, Macchi MM, Stewart JW: Controlled trial of bright light and negative air ions for chronic depression. Psychol Med 2005;35:945-955.

167 Oren DA, Wisner KL, Spinelli M, Epperson CN, Peindl KS, Terman JS, Terman M: An open trial of morning light therapy for treatment of antepartum depression. Am J Psychiatry 2002;159:666-669.

168 Epperson CN, Terman M, Terman JS, Hanusa BH, Oren DA, Peindl KS, Wisner KL: Randomized clinical trial of bright light therapy for antepartum depression: preliminary findings. J Clin Psychiatry 2004; 65:421-425.

169 Wirz-Justice A, Benedetti F, Berger M, Lam RW, Martiny K, Terman M, Wu JC: Chronotherapeutics (light and wake therapy) in affective disorders. Psychol Med 2005;35: 939-944.

170 Neumeister A, Praschak-Rieder N, Hesselmann B, Vitouch O, Rauh M, Barocka A, Tauscher J, Kasper S: Effects of tryptophan depletion in drug-free depressed patients who responded to total sleep deprivation. Arch Gen Psychiatry 1998;55:167-172.

-171 Praschak-Rieder N, Willeit M, Neumeister A, Hilger E, Kasper S: Therapeutic sleep deprivation and phototherapy (in German). Wien Med Wochenschr 1999;149: 520-524.

172 Neumeister A, Goessler R, Lucht M, Kapitany T, Bamas C, Kasper S: Bright light therapy stabilizes the antidepressant effect of partial sleep deprivation. Biol Psychiatry 1996;39:16-21.

173 Colombo C, Lucca A, Benedetti F, Barbini B, Campori E, Smeraldi E: Total sleep deprivation combined with lithium and light therapy in the treatment of bipolar depression: replication of main effects and interaction. Psychiatry Res 2000;95:43-53.
174 Parry BL, Berga SL, Mostofi N, Sependa PA, Kripke DF, Gillin JC: Morning versus evening bright light treatment of late luteal phase dysphoric disorder. Am J Psychiatry 1989;146:1215-1217.

175 Parry BL, Mahan AM, Mostofi N, Klauber MR, Lew GS, Gillin JC: Light therapy of late luteal phase dysphoric disorder: an extended study. Am J Psychiatry 1993;150:14171419.

176 Pjrek E, Konstantinidis A, Assem-Hilger E, Praschak-Rieder N, Willeit M, Kasper S, Winkler D: Therapeutic effects of escitalopram and reboxetine in seasonal affective disorder: a pooled analysis. J Psychiatr Res 2009;43:792-797.

177 Pjrek E, Winkler D, Stastny J, Konstantinidis A, Heiden A, Kasper S: Bright light therapy in seasonal affective disorder - does it suffice? Eur Neuropsychopharmacol 2004; 14:347-351.

178 Terman M, Terman JS: Bright light therapy: side effects and benefits across the symptom spectrum. J Clin Psychiatry 1999;60: 799-808; quiz 809.

179 Labbate LA, Lafer B, Thibault A, Sachs GS: Side effects induced by bright light treatment for seasonal affective disorder. J Clin Psychiatry 1994;55:189-191.

180 Swiecicki L: Phototherapy for winter depression: report of three cases (in Polish) Psychiatr Pol 1993;27:667-672.

181 Praschak-Rieder N, Neumeister A, Hesselmann B, Willeit M, Barnas C, Kasper S: Suicidal tendencies as a complication of light therapy for seasonal affective disorder: a report of three cases. J Clin Psychiatry 1997; 58:389-392.

182 Haffmans J, Lucius S, Ham N: Suicide after bright light treatment in seasonal affective disorder: a case report. J Clin Psychiatry 1998;59:478.

183 Pjrek E, Winkler D, Willeit M, Konstantinidis A, Thierry N, Kasper S: Menstrual disturbances a rare side-effect of brightlight therapy. Int J Neuropsychopharmacol 2004;7:239-240.

184 Dureau P, Jeanny JC, Clerc B, Dufier JL, Courtois Y: Long term light-induced retinal degeneration in the miniature pig. Mol Vis 1996;2:7.

185 Gallin PF, Terman M, Reme CE, Rafferty B, Terman JS, Burde RM: Ophthalmologic examination of patients with seasonal affective disorder, before and after bright light therapy. Am J Ophthalmol 1995;119:202210. 